\title{
Marine Bioluminescence AND UpPeR Ocean Physics: Seasonal Changes IN THE NORTHEAST ATLANTIC
}

\author{
By John Marra
}

About, about, in reel and rout, The death-fires danced at night: The water, like a witch's oils, Burnt green, and blue and white from "The Rime of The Ancient Mariner." by Samuel Tavlor Coleridge.

Bioluminescent

signals can be

associated with

zooplankton.
An occasional form of nightime entertainment at sea, perhaps during a transit, after the work of a particular leg is finished, is to spend time away from the ship's lights and look at the sea. Many of us have gone up to the bow (or descended into the bow dome) and, after allowing time for pupil adaptation, watched the light show.

The "show," however, also illuminates one of the more intriguing problems in biological oceanography: bioluminescence. The wheres and whys of this phenomenon remain little known, despite its apparent ubiquity throughout the marine realm. Although it has seemed merely a curiosity, such a common behavioral phenomenon must have implications for life in the sea.

Studies of bioluminescence within an oceanographic context began only in the last several years. Beginning in 1989, a group of oceanographers will continue the work of Biowatt (see Marra and Hartwig, 1984) in a program entitled Marine Bioluminescence and Upper Ocean Physics, or "Marine Light-Mixed Layers" (ML-ML). The point of view of ML-ML is that predictions of the spatial and temporal variability of bioluminescence are best achieved through better knowledge of oceanographic processes, from the forces driving the mixed layer to the waxing and waning of plankton populations.

There are two major reasons for this approach. First, due to their large size, observed bioluminescent signals can be associated with zooplankton (Marra and Hartwig, 1984; Swift et al., 1985a; Swift et al., 1985b). Although not strictly true, this is a useful simplification. Thus, the seasonal cycle of heterotrophic populations, and the predictions regarding secondary production. will be an important first step in predicting bioluminescence in the ocean. The second reason has to do with how biolumines-

John Marra, Lamont-Doherty Geological Observatory of Columbia University. Palisades, NY 10964. cence is measured. Bioluminescent light flashes commonly arise when an organism senses a disturbance in the water. Since measurements of these light flashes involve disturbing the local environment of an organism, the measurements are of bioluminescent potential. Obviously, this presents difficulty, since the strength of the disturbance affects the measured signal (natural levels of bioluminescence have not been quantified). Also, the elicited signal will depend upon the sizes of the organisms involved, and certain measuring devices may not detect the dim signal from otherwise abundant forms. For these reasons, establishing which organisms exhibit a bioluminescent response under what conditions is as important as measuring the emitted photons of a bioluminescent flash.

Both of the major oceanographic processes considered in ML-ML, mixed layer dynamics and (bioluminescent) plankton production, can have a strong seasonal component. That is, changes in mixed layer depth result from successive wintertime storms and low solar irradiance, followed by calmer winds and increased solar heating in the summer. Concordantly, the seasonal changes in mixed layer depth cause immense changes in plankton biomass, the envelope of which encompasses perhaps sharper changes in individual populations. ML-ML will focus on seasonal changes in upper layer physics and the successive populations that are responsible for bioluminescence.

Where in the open ocean are we likely to observe large signals in the seasonal cycle? Early in the planning for ML-ML, it was decided that the northeast Atlantic would be an optimal locale. From various oceanographic atlases (e.g., Robinson et al.. 1979; Isemer and Hasse, 1987), it is known that during spring the mixed layer shoals from several hundred to a few tens of meters. Signals in the plankton are correspondingly large. Some have viewed the vernal increase in phytoplankton in the North Atlantic, as seen from satellite (Esaias et al., 1986), as one of the largest transient signals on the planet (Ducklow, 1989). Bioluminescent potential also shows a large signal (E. Swift, personal communication), although its importance seasonally is not known. 


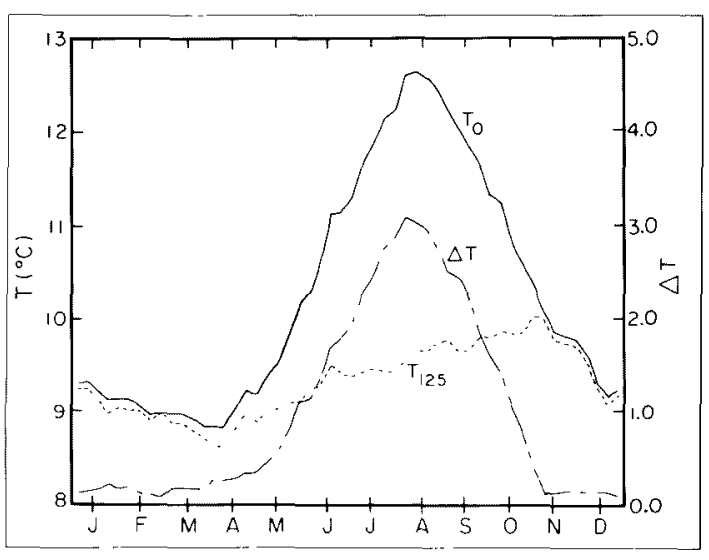

Fig. 1: Weekly-averaged sea-surface temperature $\left(T_{o}\right)$ and temperature at $125 \mathrm{~m}$ depth $\left(T_{125}\right)$ for the years 1965-1974 at Ocean Weather Station 'India' $\left(59^{\circ} \mathrm{N}, 19^{\circ} \mathrm{W}\right) . \Delta T$ is the temperature difference between $T_{o}$ and $T_{125}$. Figure re-drawn from Lambert and Hebenstreit (1984).

As a result of planning meetings thoughout 1988 , a committee of scientists settled on a site in the vicinity of $59^{\circ} \mathrm{N}, 21^{\circ} \mathrm{W}$ as suitable for our studies. This location was selected for several reasons; for example, logistical access, availability of historical data (e.g., Colebrook, 1984; Lambert and Hebenstreit, 1985), water depth, and distance from the subarctic front. The general oceanographic setting of the ML-ML site is cold, cloudy, windy and given to mesoscale variability. Water temperatures range from $9-13^{\circ} \mathrm{C}$. On the average, three-fourths of the sky is cloud-covered. Seasonally-averaged wind speeds range from $8 \mathrm{~m} \mathrm{~s}^{-1}$ in the summer to $18 \mathrm{~m} \mathrm{~s}^{-1}$ in winter. The North Atlantic Current. with its extensive field of meanders and eddies (Krauss and Meincke, 1985), flows through the area.

\section{Synopsis of the Seasonal Cycle}

The January-March period in the northeast Atlantic is characterized by a net loss of heat from the ocean to the atmosphere, resulting in convective cooling of the water column. Estimates of the heat loss average about $200 \mathrm{~W} \mathrm{~m}^{-2}$ in January (Isemer and Hasse, 1987). This magnitude can be appreciated, as pointed out by Stommel (1979), by comparison with the solar flux at $50^{\circ} \mathrm{N}$ latitude in June, under cloudless skies, of $375 \mathrm{~W} \mathrm{~m}^{-2}$.

Convective cooling during January-March produces deep mixed layers of several hundred meters (Robinson et al., 1979). These depths are difficult to specify more exactly because the mixed layer is difficult to define, and because the actual physical process producing the deepening is uncertain. Also apparent in the charts in Robinson et al. (1979) is an advective heat input from the Gulf Stream and North Atlantic Current. The advective heat input is necessary to balance the vertical heat flux. During the January-March period, the low water column irradiance prevents phytoplankton growth, and deep mixing establishes the total new nutrients available to the ecosystem as it develops through later warming and periods of low vertical exchange. Although measurements in winter have not been published, phytoplankton populations are expected to be very low; data from the Coastal Zone Color Scanner suggest values in the range of $0.1-0.2 \mathrm{mg} \mathrm{m}^{-3}$ (W. Esaias, personal communication). Although we know very little of over-wintering populations of zooplankton, they might consist of species such as those of the genus Metridia, whose life cycle is less tuned to the spring phytoplankton increase, or large carnivorous forms such as Euchaeta and Pleuromamma.

By April, the water column begins to stratify (Fig. 1) and the winds begin to subside. The first increases in chlorophyll have been noted in the data at this time (Williams and Hopkins, 1974), probably dominated by early forms such as Skeletonema costatum, Thalassiosira spp. and Chaetoceros spp. May is typically the month of the phytoplankton bloom at this latitude, and chlorophyll values can be as high as 2 $5 \mathrm{mg} \mathrm{m}^{-3}$. This is also the time when Calanus finmarchicus and $C$. helgolandicus ascend to the surface for maturation, grazing and reproduction. Heterotrophic dinoflagellates, of the genus Protoperidinium, have been observed to graze on diatoms, sometimes exclusively (Jacobsen and Anderson, 1986).

By early June, the various plankton populations characteristic of spring have reached their peak in biomass. Other planktonic forms, such as euphausiids, make their appearance (Tett, 1972; Colebrook, 1984; Williams and Lindley, 1982), as do siphonophores and ctenophores (Williams and Conway, 1981); thus begins a transition to the summertime community, in the phytoplankton commonly characterized by dinoflagellates and a few species of Rhizosolenia (Colebrook, 1984). The spring increase in phytoplankton appears to give way to greater spatial heterogeneity in chlorophyll (Strass and Woods, 1988; also seen in the data of Williams and Conway, 1981). This may be a manifestation of phytoplankton growth associated with upwelling along the borders of anticyclonic mesoscale eddies (Woods, 1988).

August is the month of greatest water column stability (Fig. 1), and both August and September are the months when the summer plankton community species (as described above) reaches its maximum. In September, there is some evidence for a fall bloom as stratification declines. By late October, although surface water temperatures are above their seasonal minimum, mixed layer depths have increased to greater than $100 \mathrm{~m}$.

\section{A Program of Study}

Bioluminescence is often correlated with the abundance of heterotrophs. Thus maximum bioluminescent potential, according to the current data, should occur in August when heterotrophic populations are at their maximum. In an operational sense, we might develop a crude model for the seasonal change in bioluminescent potential based on sea-surface temperature or water column stability. This is a useful
$\mathrm{M}$

bioluminescent

potential, according

to the current data,

should occur in August

when heterotrophic

populations are at their

maximum. 
A relationship

between

bioluminescence and

chlorophyll may not be

readily apparent. first step, but it omits several important factors. First, spatial variability in the physical fields, which are driving forces in the variability of production (e.g., Woods, 1988), with attendant time lags, will probably obscure any simple relationships with physical properties.

Second, diurnal vertical migration is an important component of bioluminescent potential (Marra and Hartwig, 1984; Swift et al.; Swift et al., 1985), and the causative factors (e.g., avoidence of predators) and environmental signals (e.g. irradiance levels, food availiabilty) for this phenomenon continue to be an ongoing research concern. One interesting facet of vertical migration in the northeast Atlantic involves Metridia lucens and Pleuromamma sp., two species we believe to be particularly important to bioluminescence in the ML-ML area. According to Roe (1984), only the females of these species migrate. Diurnal vertical migration is one of many types of interactions within and among the various plankton groups that will influence bioluminescent behavior.

spatial variability of the bloom and to identify the major bioluminescent organisms. There will also be a collaborative cruise with the Naval Ocean Research and Development Activity (NORDA) for September of that year for further identification of organisms responsible for bioluminescence. Both of these major experiments will be done in preparation for 1991, the major field year, which will include the installation of a mooring and cruises spanning the productive seasons.

\section{Acknowledgements}

This article could not have been written without input from those involved in the planning of ML-ML. Information and commentary from K. Baker, A. Brandt, A. Bucklin, J. Case, T. Dickey. B. Frost, E. Hartwig, M. Latz, D. Ondercin, M.J. Perry, R. Smith, R. Spinrad. E.Swift, R. Trask, R. Weller, A. Weidemann, and J. Wroblewski is gratefully acknowledged. I thank H.P. Batchelder and $\mathrm{K}$. Carder for comments on the manuscript.

\section{References}

Buskey, E.J. and E. Swift, 1987: Prediction of natural bioluminescence in the Sargasso Sea using an encounter model. $E O S 68.1695$.

Although we have made significant progress in identifying these (e.g., Buskey and Swift, 1987; Swift et al. . 1988), the problem requires considerable study.

Heterotrophic dinoflagellates, including Protoperidinium, may be a significant fraction of the bioluminescent signal in the ML-ML area (Swift et al., personal communication). If so, this would simplify the understanding of bioluminescence, since, as weakly-swimming grazers, they will be expected to have a more direct relationship, temporally and spatially, to chlorophyll-a, a representative property of their prey. Some puzzles exist, however. As stated above, many species could be grazers on diatoms. But the dinoflagellate and diatom species identified by Colebrook (1984) are seasonally out of phase with one another. Lessard and Swift (1985), from isotope incorporation data, suggest that heterotrophic dinoflagellates feed on bacteria as well as phytoplankton. Thus, a relationship between bioluminescence and chlorophyll may not be readily apparent, meaning that a broader range of bio-optical indicators associated with phytoplankton will have to be investigated (Carder et al., 1989).

An interesting and unexplored area of bioluminescence is that of signal transmission. This will depend not only on the strength of the bioluminescent flash (a biological property), but also on the optical characteristics (absorption, scattering) of the water itself. Is bioluminescent potential related to the magnitude of absorption or scattering? Do the inherent optical properties affect the empathic or behaviorally-propagated (e.g., Neshyba, 1967) bioluminescent displays?

The general program for ML-ML, as currently scheduled, is as follows. For 1989, we are embarking on a pilot mooring experiment (see Dickey et al., 1986), plus cooperative field work with the JGOFS North Atlantic Bloom Experiment (Ducklow, 1989). In 1990, we are planning a cruise for the period of the spring phytoplankton bloom to access the detailed
Carder, K.L., R.G. Steward, G.R. Harvey, P.B. Ortner, 1989: Marine humic and fulvic acids: their effects on remote sensing of ocean chlorophyll. Limnol. Oceanogr. 34.6881.

Colebrook.J. M., 1984: Continuous plankton records: relationships between species of phytoplankton and zooplankton in the seasonal cycle. Mar. Bio. 313-323.

Dickey, T., E. Hartwig and J. Marra, 1986: The Biowatt biooptical and physical moored measurement program. EOS, 67,650 .

Ducklow, H.W., 1989: Joint Global Ocean Flux Study: The 1989 North Atlantic Bloom Experiment. Oceanogr. Mag. 2(1). 4-7.

Esaias, W., G. Feldman, C. McClain, J.A. Elrod, 1986: Monthly satellite-derived phytoplankton pigment distribution for the North Atlantic Ocean Basin. EOS 68. 835.

Gill, A.E., 1982: Atmosphere-Ocean Dynamics. Academic Press, 662.

Isemer, H.-J. and L. Hasse, 1987: The Bunker Climate Atlas of the North Atlantic Oceans, Vols. 1 (181 charts, 31 figures) and 2 (207 charts, 37 figures). Springer-Werlag, Berlin.

Jacobson, D.M. and D. M. Anderson, 1986: Thecate heterotrophic dinoflagellates: feeding behavior and mechanisms. $J$. Phycol. 22, 249-258.

Krauss, W. and J. Meincke, 1985: Drifting buoy trajectories in the North Atlantic Current. Nature 296, 737-740.

Lambert, R. B., Jr. and G. T. Hebenstreit, 1985: Upper ocean stratification and the variability in the North Atlantic, SAIC-84/1778, Science Applications International

Lessard, E. and E. Swift, 1985: Species-specific grazing rates of heterotrophic dinoflagellates in oceanic waters, measured 289-296.

Marra, J. and E.O. Hartwig, 1984: Biowatt: A study of bioluminescence and optical variability in the sea. EOS. $65.732-733$.

Neshyba, S., 1967: Pulsed light stimulation of marine bioluminescence in situ. Limnol. Oceanogr., 12, 222-235.

Robinson, M.K., R.A. Bauer and E.H. Schroeder, 1979: Atlas of North Atlantic Ocean monthly mean temperatures and mean salinities of the surface layer. U.S. Naval Oceanogr. Off. Ref. Publ. 18, 1339 pp.

Roe, H.S.J., 1984: The diel migrations and distributions within a mesopelagic community in the north east Atlantic. 4. The copepods. Prog. Oceanog. 13, 353-388.

[ Please turv to page 52 ] Corporation, McLean, Va. with a dual-label radioisotope technique. Mar. Biol. 87 . 


\section{JoInT GLOBAL OCEAN}

[ Continued From PAge 7 ]

Deuser, W.G., 1986: Seasonal and interannual variations in deep-water particle fluxes in the Sargasso Sea and their relation to surface hydrography. Deep-Sea Research. 33, 225-246.

Evans, G.T. and J.S. Parslow, 1985: A model of annual plankton cycles. Biol. Oceanogr., 3 , 327-347.

Gran, H.H. and T. Braarud, 1935: A quantitative study of the phytoplankton in the Bay of Fundy and the Gulf of Maine including observations on the hydrography, chemistry and turbidity. J. Biol. Bd. Canada, 1, 219-467.

Hensen, V.. 1887: Ueber die Bestimmung des Planktons oder des im Meere treibenden Materials an Pflanzen und Thieren. In: Fuenfter Bericht der Kommission z. wiss. Untersuchg. d. dt. Meere in Kiel f. d. Jahre 1882-1886, Berlin, 1-107 pp.

Krümmel, O., 1892: Einige Ergebnisse der Expedition. In: Reisebeschreibung der Plankton-Expedition nebst Einleitung von Dr. Hensen und Vorberichten von Drs Dahl, Apstein, Lohmann, Borgert, Schutt und Brandt. Kiel und Leipzig, $370 \mathrm{pp}$ mit 100 Figuren im Text, sowie 5 Karten, 2 Tafeln und einer Photogravur, $18-46 \mathrm{p}$.

Menzel, D.W. And J.H. Ryther, 1960: The annual cycle of primary production in the Sargasso Sea off Bermuda. Deep-Sea Res., 6, 351-67.

Moore, III, B. and B. Bolin, 1986: The oceans, carbon dioxide and global change. Oceanus 29(4).915

Radach. G., J. Berg, and B. Heinemann, 1984: On the relation of primary production to grazing during the Fladen Ground Experiment. 1976. In: Flows of energy and materials in Marine ecosystems, M.J.R. Fasham. Ed.. Plenum. New York, 597-628.

Smayda. T.J., 1970: The suspension and sinking of phytoplankton in the sea. Oceanogr. Mar. Biol. Annu. Rev., 8, 353-414.

Smetacek, V.. 1985: Role of sinking in diatom life history cycles: ecological, evolutionary, and geological significance, Mar. Biol. 84. 239 251.

Sverdrup, H.U., 1953: On conditions of vernal blooming of phytoplankton. J. Cons. Exp. Mer., 18, 287-295

Walsh, J., 1988: On the nature of continental shelves. Academic Press, New York, 520 pp.

Watson, A.J. and M. Whitfield, 1985: Composition of particles in the global ocean. Deep-Sea Res. 32, 1023-1039. 口

\section{Marine Bioluminescence}

\section{[ CONTINUED FROM PAGE 38 ]}

Stommel, H. 1979: Oceanic warming of western Europe. Proc. Natl. Acad Sci. USA, 76, No.6 2518-2521.

Strass, V. and J. D. Woods, 1988: Horizontal and seasonal variation of density and chlorophyll profiles between the Azores and Greenland. In: Towards a Theory of Biological-Physical Interactions in the World Ocean, ed. B.J. Rothschild. D. Reidel, Dordrecht, The Netherlands, 113-136.

Swift, E., W.H. Biggeley, P.G. Verity, D.T. Brown 1983: Zooplankton are major sources of epipelagic bioluminescence in the southern Sargasso Sea. Bull. Mar. Sci. 33. 855-683.

Swift, E.,C.R. Booth, J. Van Keuren, H.P. Bathcelder, C.P. Li, 1988: A moored instrument to meas-

\section{BY-LAWS}

\section{[ CONTINUED FROM PAGE 43 ]}

4. A quorum for the transaction of business at an Annual Meeting shall be at least two percent of the members present who are eligible to vote on May 1 of that year. The affirmative vote of a majority of the members present who are eligible to vote shal be required tor the resolution of any question.

The Council may make other rules for meetings not inconsistent with the Articles of Incorporation or Bylaws. Business not set forth in the notice of the meeting shall not be transacted if three members eligible to vote object.

5 The Society may organize, sponsor, or co-sponsor such additional local, national, or international meetıngs as may be authorized by the Councit.

6 The fiscal year of the Society shall conform to the calendar year

ARTICIE XII. Publications.

The Society shall issue an official publication and such additional journals, papers, books and the like as may be authorized by the Council.

ARTICLE XIII. Amendments to the Bylaws

1. No part of the Bylaws shall be amended or annulled except by mail ballot in the following manner: A proposed amendment shall be approved by the Coun a petition signed by at least five percent of the members eligible to vote on the preceding May 1 The proposed amendment, with the reasons therefore, shall be published in the official publication of the Society at least nınety days before ballots for the amend. ment are malled.

2. A proposed amendment, accompanied by a ballot, shall be mailed by the Executive Officer to each member eligible to vote at least sixty days prior to the designated date the ballots are to be counted. The ballots to be counted must be received by the counted. The ballots to be counted must be received by the the ballots.

3. The adoption of a proposed amendment shall require the affirmative votes of at least two-thirds of all members voting. ure stimulated and natural oceanic bioluminescence, Ocean Optics IX. ed. by M. Blizard. Proc. Society of Photo-Optical Instrumentation Engineers, 925. 76-96.

Swift, E., J.C. Dugas, P. Neidhardt, 1985a: Boiluminescence in Icelandic waters. American Society of Limnology and Oceanography, 48th Annual Meeting Abstract.

Swift, E., E.J. Lessard, and W.H. Biggeley, 1985b: Organisms associated with stimulated epipelagic bioluminescence in the Sargasso Sea and Gulf Stream. J. Plankton Res. 7.831848.

Tett, P.B.. 1972: An annual cycle of flash induced luminescence in the euphausiid Thvsanoessa raschii. Mar. Biol. 12. 207-218.

Williams, R. and D.V.P. Conway, 1981: Vertical distributions and seasonal abundance of Aglantha digitale (O.F. Muller) (Coelenterata: Tra-

\section{ASSIMILATION OF OBSERVATIONS}

\section{[ CONTINUED FROM PAGE 50 ]}

before the symposium starts. The extended abstracts of the papers (up to six pages) prepared according to the instructions to be distributed later should be submitted no later than December 15, 1989, to: The Secretary-General of WMO; Attention PTR; World Meteorological Organization; 41. av. Giuseppe-Motta: Case postale No 5; CH-1211 Geneva 20; with a copy sent to the chairman of the IPC: Dr. O. Talagrand; Laboratoire de Météorologie Dynamique; Ecole Normale Supérieure ; 24, rue Lhomond: F-75231 Paris Cedex 05.

Participants will be notified of the acceptance of their papers by the IPC before March 1, 1990. For further information concerning the symposium, please refer to the above mentioned two addresses. J. Labrousse. Research and Development Programme Department. World Meteorological Organization chymedusae) and other planktonic coelenterates in the northeast Atlantic Ocean. J. Plank. Res. 3, 633-643.

Williams, R. and C.C. Hopkins, 1974: Sampling at Ocean Weather Station INDIA $\left(59^{\circ} \mathrm{N} 19^{\circ} \mathrm{W}\right)$ in 1974. Annls Biol. 31, 57-60

Williams, R. and J.A. Lindley, 1982: Variability in abundance. vertical distribution and ontogenetic migrations of Thysanoessa longicaudata (Crustacea: Euphausiacea) in the north-eastern Atlantic Ocean. Mar. Biol. 69, 321-330.

Woods. J., 1988: Mesoscale upwelling and primary production. In: Towards a Theory of Biologi cal-Phvsical Interactions in the World Ocean. ed. B.I. Rothschild, D. Reidel, Dordrecht, The Netherlands, 7-38. $\square$

The Bermuda Biological Station for Research, Inc. Announces Opportunities for Research and Coursework in Blue-Water Oceanography and Subtropical Marine Science.

Financial aid is available for exploratory research, summer courses and graduate thesis work. Facilities include a UNOL-supported vessel and a well-equipped laboratory wing. 1989 course topics include larval biology, zooplankton ecology, global environmental change, ecophysiology of corals, seagrasses and mangroves, hazard assessment and ecological statistics. For more information, contact:

Dr. Susan B. Cook, Assistant Director

Bermuda Biological Station for Research, Inc.

17 Biological Lane

Ferry Reach GE 01 Bermuda

Tel: 809-297-1880

FAX: 809-297-8143 